\title{
GROUND-BASED REMOTE SENSING FOR ESTIMATING THE CUMULATIVE EFFECT OF DIFFERENT IRRIGATION WATER QUALITIES ON THE PRODUCTIVITY AND GROWTH OF POTATO
}

\author{
Elsayed, S. $^{(1)}$ and M. M. Ibrahim ${ }^{(2)}$
}

\begin{abstract}
The growing competition of water available from Nile fresh water, coupled with laws limiting ground water pumping, has led to utilization of different water qualities in irrigation proposals. In this study, the effect of mixed water on yield, biomass and relative chlorophyll meter was estimated. The performance of ground-based remote sensing of hyperspectral passive reflectance sensor and digital image analysis as precision agriculture tools was tested at tubers bulking growth stage to assess their relationship to detractively measured parameters via simple linear regression and three models based on partial least square regression $(P L S R)$ analysis. The results showed that the newly developed indices $\left(R_{970}-R_{730}\right) /\left(R_{970}+{ }_{R 730}\right)$ and $\left(R_{990}-R_{730}\right) /\left(R_{990}+{ }_{R 730}\right)$ showed close and highly significant associations with yield, biomass and relative chlorophyll meter, with $R^{2}$ values reach to $0.87,0.80$, and 0.86 , respectively, while the green cover (\%) was highly significantly related the same parameters, with $R^{2}$ values reach to of $0.82,0.73$ and 0.70 , respectively. Three models of PLSR based on $(i)$ the spectral reflectance from 302 to $1148 \mathrm{~nm}$, (ii) selected nine spectral indices and (iii) selected eight red-blue-green (RBG) indices of the images analysis for the measured parameters were apparently useful for estimating the yield, aerial biomass and relative chlorophyll meter of potato cultivar under fresh and mixed water treatments. In conclusion, the assessment of measured parameters was improved and more robust when using the multivariate analysis of PLSR models than with previously assayed normalized difference spectral indices and RGB indices from digital image analysis.
\end{abstract}

Key words: sewage water, remote sensing, precision agriculture, spectral indices, $R G B$ indices, potato

\footnotetext{
${ }^{1}$ Assistant Prof. of Agric. Eng. Evaluation of Natural Resources Department, Environmental Studies and Research Institute, Sadat City University.

${ }^{2}$ Assistant Prof. of Agric. Eng. Dept., Faculty of Agric., Al-Mansoura University
} 


\section{INTRODUCTION}

The situation of water shortage in arid and semiarid regions is getting worse due to the unexpected climatic changes, continuous population growth and increasing consumption of fresh water in the agricultural sector which consumes about $75 \%$ (El-Hendawy et al., 2015). In Egypt, the total water requirements reached around 72.4 billion $\mathrm{m}^{3}$ but annual water supply from the River Nile, rainfall is approximately 57.7 billion $\mathrm{m}^{3}$. The growing competition of water available from Nile fresh water, coupled with laws limiting ground water pumping, has led to utilization of low quality water in irrigation proposals (Allam et al., 2013). Some regions of Nile Delta suffer from fresh water shortage for irrigation proposal. For that, the farmers are forced to use the waste water such as sewage water and mixed water for irrigation process from the surrounding drainages. Waste water supplies a part of essential elements for plant productive and soil fertility. But for long-term irrigation with sewage water or industrial water could be restricted soil function and nutrients uptake. Sewage water contents higher percentage of suspended solids, electrolytes dissolved organic matter, biochemical and chemical oxygen demand than fresh water. This leads to sewage water can directly change soil physical and hydraulic properties (Yadar et al., 2002). Therefore, this work focuses on study the effect of the long-term accumulative of mixed water (sewage water mixed with drainage water) on yield and plant growth of potato cultivar. For estimating these parameters by tradition methods are time consuming and required several samples to cover the full area of the field. In the field, frequent changes in environmental conditions may further influence the measurements and thus need fast measurements (Elsayed et al. 2015 b; Winterhalter et al. 2011). Therefore, it is very important to develop ground-based remote sensing methods for assessment aerial biomass, relative chlorophyll meter (SPAD value) and yield of cultivars which should be reliable, fast, simple, practical, and economic. The early detection of mixed water (MW) effect on theses parameters by sensing methods such as passive reflectance sensing and digital image analysis is crucial because it could help to detect status of plant at larger temporal and spatial scales before any damage is clearly visible. 
Passive reflectance sensor has been tested to assessment aerial biomass, dry biomass, nitrogen status and grain yield under different nitrogen fertilizer and irrigation regimes conditions (Rischbeck et al. 2016, Erdle et al., 2011). Passive sensor systems depend on sunlight as a source of light. Several studies suggested that the and grain yield could be estimated using spectral reflectance during different growth stages (Schmidhalter et al. 2001; El-Shikha et al. 2007; Gutierrez et al. 2010). For example, the normalised water stress index 1 (NWI-1; ( $\mathrm{R}_{970}-$ $\left.\mathrm{R}_{900}\right) /\left(\mathrm{R}_{970}+\mathrm{R}_{900}\right)$ ) and the normalised water index 2 (NWI-2; $\left(\mathrm{R}_{970}-\right.$ $\left.\mathrm{R}_{850}\right) /\left(\mathrm{R}_{970}+\mathrm{R}_{850}\right)$ ), as well as the normalised water index 3 (NWI-3; $\left.\left(\mathrm{R}_{970}-\mathrm{R}_{920}\right) /\left(\mathrm{R}_{970}+\mathrm{R}_{920}\right)\right)$ and the normalised water index 4 (NWI-4; $\left.\left(\mathrm{R}_{970}-\mathrm{R}_{880}\right) /\left(\mathrm{R}_{970}+\mathrm{R}_{880}\right)\right)$ from passive reflectance sensor measurements demonstrated great potential at differentiating high- and low-yielding genotypes in advanced lines of spring wheat under well-irrigated, waterstressed and high-temperature conditions in diverse trials (Gutierrez et al. 2010).

The application of digital cameras and image processing techniques is less expensive than the use of other techniques, such as passive reflectance sensing and technologies of satellite imagery. A color camera output can be de-coded into three images to represent the red, green and blue (RGB) components of the full image. The RGB components of the color image can be recombined using software or hardware to produce intensity, saturation and hue images, which can be more convenient for subsequent processing. The applications of digital cameras by using RGB has been proven to be a potential source to estimate several canopy parameters such as the crop growth (Paruelo et al., 2000; Lee and Lee, 2013), the leaf chlorophyll content (Hu et al., 2013), the nitrogen status (Jia et al., 2014), the differentiation of early plant vigour (Kipp et al., 2014), the senescence of wheat (Adamsen et al., 1999) and the vegetation cover (Lukina et al., 1999). For example, Paruelo et al. (2000) found that the percentage of green pixels of images and green grass biomass showed a good curvilinear relationship when data were pooled from three sampling dates. A strong relationship was found between the relative amount of green pixels, and the early vigour index of 50 winter wheat cultivars (Kipp et al., 2014). 
An alternative approach in this study is to conduct a partial least square regression (PLSR) analysis of hyperspectral reflectance, spectral indices and image analysis data. This approach is a chemometric technique that creates orthogonal latent parameters across the input parameters (single wavebands) and relates them to the target parameters by generalizing and combining the methods of principal component analysis and multiple regressions (Sharabian et al. 2014). Therefore, it could be used to predict a set of dependent parameters from a large set of independent ones (i.e., predictors) that may be correlated. Elsayed et al. (2015 a) found that PLSR based on spectral reflectance could be used for predict the pod yield of peanut cultivars as well as biomass of winter wheat (Li et al. 2014).

To the best of our knowledge, there is very little information available about the comparative assessments of the performance of passive reflectance sensor and digital image camera for assessing the aerial biomass, relative chlorophyll and yield of potato under mixed and fresh water.

The purpose of this work was (i) to study the effect of long term accumulative of mixed water on the aerial biomass, relative chlorophyll and yield of potato cultivar (ii) to assess whether spectral and RGB indices can reflect changes in the abovementioned parameters, (iii) to compare the performance of three models of PLSR to predicted the abovementioned parameters of potato under the year effect or treatment effect.

\section{MATERIALS AND METHODS}

The present study was conducted at Manyt Elnasr, Dakahlia Governorate, Egypt (Latitude: N 31 5' .20", Longitude: E 31 41' 20") during two years 2014-2015 and 2015 -2016. This region is characterized by a semiarid climate with moderate cold winters and warm summers. Some fields in this region are seriously lacking from Nile fresh water. Since more than 10 years, the farmers in this region use mixed water as sewage water with drainage water for irrigation. In this study, two sites from this region (first site; irrigated with Nile fresh water and second site; irrigated with mixed water) were selected. Potato seed pieces were sown on 10 January 2015 and 13 January 2016 in clay loam. Potato seed pieces were planted 
manually using a hand tool to dig holes at $25 \mathrm{~cm}$ intervals. Fertilizer (300 $\mathrm{kg} \cdot \mathrm{fed}^{-1}$ in the form of ammonium nitrate $(33.5 \% \mathrm{~N}), 75 \mathrm{~kg} \cdot \mathrm{fed}^{-1}$ in the form of Superphosphate (15.5\% P2O5) and $96 \mathrm{~kg} \cdot \mathrm{fed}^{-1}$ in the form of potassium sulphate $(48 \% \mathrm{~K} 2 \mathrm{O})$ was applied uniformly at the early to full growing vegetative stages across the experiment as recommended for potato production in this area. The soil of the experimental site has water field capacity of $43 \%$, welting point of $22.4 \%$ and bulk density of 1.31 $\mathrm{g} \cdot \mathrm{cm}^{-3}$.The surface irrigation is applied based on potato water-use, which varied seasonally from 7 to 9 irrigations for all sites. Irrigation water applied used fresh water with an EC $=358 \mathrm{ppm}, \mathrm{TDS}=232 \mathrm{mg} / \mathrm{L}, \mathrm{pH}=$ $7.45, \mathrm{Ca}^{++}=1.2 \mathrm{meq} / \mathrm{L}, \mathrm{Mg}^{++}=1.8 \mathrm{meq} / \mathrm{L}, \mathrm{Na}^{++}=1.6 \mathrm{meq} / \mathrm{L}, \mathrm{K}^{++}=0.2$ $\mathrm{meq} / \mathrm{L}, \mathrm{Cl}^{-}=6.6 \mathrm{meq} / \mathrm{L}$, and $\mathrm{SAR}=0.92$ ). Irrigation water applied used mixed water with an $\mathrm{EC}=1152 \mathrm{ppm}$, TDS $=747 \mathrm{mg} / \mathrm{L}$ and $\mathrm{pH}=7.62$, $\mathrm{Ca}^{++}=1.4 \mathrm{meq} / \mathrm{L}, \mathrm{Mg}^{++}=4.4 \mathrm{meq} / \mathrm{L}, \mathrm{Na}^{++}=7.2 \mathrm{meq} / \mathrm{L}, \mathrm{K}^{++}=0.9 \mathrm{meq} / \mathrm{L}$, $\mathrm{Cl}^{-}=6.6 \mathrm{meq} / \mathrm{L}$, and $\mathrm{SAR}=4.2$ ). Soil analysis used fresh water with an $\mathrm{EC}=545 \mathrm{ppm}, \mathrm{TDS}=354 \mathrm{mg} / \mathrm{L}, \mathrm{pH}=7.61, \mathrm{Ca}^{++}=1.8 \mathrm{meq} / \mathrm{L}, \mathrm{Mg}^{++}=$ $2.9 \mathrm{meq} / \mathrm{L}, \mathrm{Na}^{++}=4.4 \mathrm{meq} / \mathrm{L}, \mathrm{K}^{++}=0.4 \mathrm{meq} / \mathrm{L}, \mathrm{Cl}^{-}=3.9 \mathrm{meq} / \mathrm{L}$, and $\mathrm{SAR}$ = 2.48). Soil analysis used mixed water with an $\mathrm{EC}=1310 \mathrm{ppm}$, TDS $=$ $850 \mathrm{mg} / \mathrm{L}, \mathrm{pH}=8.14, \mathrm{Ca}^{++}=3 \mathrm{meq} / \mathrm{L}, \mathrm{Mg}^{++}=5 \mathrm{meq} / \mathrm{L}, \mathrm{Na}^{++}=9.8$ $\mathrm{meq} / \mathrm{L}, \mathrm{K}^{++}=0.2 \mathrm{meq} / \mathrm{L}, \mathrm{Cl}^{-}=4.4 \mathrm{meq} / \mathrm{L}$, and $\left.\mathrm{SAR}=4.9\right)$.

\section{Description of passive reflectance sensor and spectral reflectance measurements}

A passive bi-directional reflectance sensor (tec5, Oberursel, Germany) measuring wavelengths between $302-1148 \mathrm{~nm}$, with a bandwidth of 2 $\mathrm{nm}$ and connected to a portable computer and geographical positioning system (GPS), was used. The handheld FieldSpec sensor consists of two units. One unit was linked with a diffuser and measured the light radiation as a reference signal. The second unit measured the canopy reflectance with a fiber optic (Elsayed et al. 2015 a; Rischbeck et al. 2016) with an aperture of $12^{\circ}$ and a field of view of $0.2 \mathrm{~m}^{2}$ from one meter of height. The aperture of an optical system is the opening that determines the cone angle of a bundle of rays that enter the optics. The sensor outputs were co-recorded along with the GPS coordinates when collecting information in the field from sixteen position of each site. The actual sensor output was co-referenced and recorded for each position. Afterwards, readings 
within one position of the field were averaged to a single value. The canopy reflectance was calculated with the readings from the spectrometer unit and corrected with a calibration factor obtained from a reference grey standard. Spectral measurements were mostly taken on sunny days at nadir direction approximately $1 \mathrm{~m}$ above the canopy. Readings were taken during tubers bulking $(\mathrm{BBCH} 7 \mathrm{~N})$ growth stage nearly all berries in the fructification have reached full size (or have been shed) at two years.

\section{Selection of spectral reflectance indices}

In Table 1, nine spectral indices from different sources are listed with the respective references. In this study, we calculated and tested both known and novel indices. A contour map analysis for all wavelengths of the hyperspectral passive sensor (from 302 to $1048 \mathrm{~nm}$ ) was used to select some normalized difference indices. The selected indices generally presented more stable and strong relationships with aerial biomass, relative chlorophyll meter and potato yield. All possible dual wavelength combinations were evaluated depending on a contour map analysis for the hyperspectral passive sensor. Contour maps are matrices of the coefficients of determination of all variable measurements with all possible combinations of binary, normalized spectral indices (Fig. 2). The "lattice" package from the software $\mathrm{R}$ statistics version 3.0.2 (R foundation for statistical computing 2013) was used to produce the contour maps from the hyperspectral reflectance readings; thirteen wavelengths $(600,620,630,680,720,730,734,740,760,780,880,970$ and $990 \mathrm{~nm}$ ) were therefore used to calculate the reflectance indices given in Table 1.

\section{Description of digital images measurements and analysis}

The samples of potato plants were photographed by using a Kodak D5100 reflex camera with a 14-megapixel resolution at sixteen positions for each site. The camera was manually held and oriented vertically downwards toward the potato plants at a distance of $1.50 \mathrm{~m}$ under cloudy conditions to avoid shadows. The digital images were converted from JPEG to PPM file format using IrfanView 4.37. $\mathrm{R}$ statistics 3.0.2 ( $\mathrm{R}$ foundation for Statistical Computing 2013) with the R package "pixmap" was used to calculate eight RGB indices from digital image analysis according to the 
pixels red (R), green $(\mathrm{G})$, and blue (B) in Figure 4. Such as (Plant cover $(\%)$ is total image pixels to the harvest area, Green cover (\%) is total green area to harvest area, Red pixels (\%) is proportion of red pixels for the whole image, Green pixels (\%) proportion of green pixels for the whole image, Blue pixels (\%) is proportion of blue pixels for the whole image, the Visible Atmospheric Resistant Index (VARI) is (Green Red)/(Green + Red -Blue), the Normalized Difference Vegetation Index (NDVI) is (Green- Red)/( Green + Red ), the Normalized Difference Vegetation Index1 (NDVI1) is (Red - Blue)/(Red + Blue)) were tested for estimating potatoes yield, biomass and SPAD value.

\section{Destructively measured parameters}

Aerial biomass, relative chlorophyll meter and potato yield were determined in two fields experimental under fresh and mixed water. Sixteen position from each field was selected and five plants from each position were randomly taken after digital image and passive reflectance measurements at tubers bulking growth stage to determine the aerial biomass weight by using the accuracy digital balance. The relative chlorophyll meter was taken to be the average value from five leaves for each plant as obtained from a portable chlorophyll meter (SPAD-502). At harvest time, also the average of five plants from each position was randomly taken to determine the potato yield per plant.

Table 1. Spectral reflectance indices, formula and references of new spectral indices developed and used in this study.

\begin{tabular}{l|l|l}
\hline \multicolumn{1}{c|}{ Formula } & Index abbreviation & \multicolumn{1}{c}{ References } \\
\hline$\left(\mathrm{R}_{970}-\mathrm{R}_{720}\right) /\left(\mathrm{R}_{970}+\mathrm{R}_{720}\right)$ & HPS $970 \_720$ & This study \\
$\left(\mathrm{R}_{970}-\mathrm{R}_{730}\right) /\left(\mathrm{R}_{970}+\mathrm{R}_{730}\right)$ & HPS 970_730 & This study \\
$\left(\mathrm{R}_{970}-\mathrm{R}_{734}\right) /\left(\mathrm{R}_{970}+\mathrm{R}_{734}\right)$ & HPS 970_734 & This study \\
$\left(\mathrm{R}_{990}-\mathrm{R}_{730}\right) /\left(\mathrm{R}_{990}+\mathrm{R}_{730}\right)$ & HPS 990_730 & This study \\
$\left(\mathrm{R}_{780}-\mathrm{R}_{760}\right) /\left(\mathrm{R}_{780}+\mathrm{R}_{760}\right)$ & HPS 780_760 & This study \\
$\left(\mathrm{R}_{680}-\mathrm{R}_{620}\right) /\left(\mathrm{R}_{680}+\mathrm{R}_{620}\right)$ & HPS 680_620 & This study \\
$\left(\mathrm{R}_{880}-\mathrm{R}_{740}\right) /\left(\mathrm{R}_{880}+\mathrm{R}_{740}\right)$ & HPS $880 \_740$ & This study \\
$\left(\mathrm{R}_{680}-\mathrm{R}_{630}\right) /\left(\mathrm{R}_{680}+\mathrm{R}_{630}\right)$ & HPS 680_630 & This study \\
$\left(\mathrm{R}_{680}-\mathrm{R}_{600}\right) /\left(\mathrm{R}_{680}+\mathrm{R}_{600}\right)$ & HPS 680_600 & This study \\
\hline
\end{tabular}

HPS: Hyperspectral passive sensor 


\section{Modelling of destructively measured parameters}

Sigmaplot for Windows v.12 (Systat software Inc., Chicago), and SPSS 16 (SPSS Inc., Chicago, IL, USA) were used for the statistical analysis. Simple linear regressions were calculated to analyse the relationships between spectral and RGB indices with grain yield, aerial biomass and SPAD value of potato cultivar (Tables 3 and 4). Coefficients of determination and significance levels were determined; nominal alpha values and 0.001 were used (Tables 3 and 4). The Unscrambler $X$ multivariate data analysis software version 10.2 (CAMO Software AS, Oslo) was used to calibrate and validate the partial least square models. Partial Least Square Regression (PLSR) creates orthogonal latent variables across the input variables and relates them to the variables measurements. This is a way to cope with redundancy among the input variables. In this study, the PLSR searches for the sensitive information from spectral reflectance, spectral indices and RGB indices of the digital image analysis. Three models of PLSR based on (i) the spectral reflectance from 302 to $1148 \mathrm{~nm}$, (ii) selected nine spectral indices (Table 1) (iii) selected eight RBG indices of the image analysis for the measured parameters were used as input variables in the PLSR models, as shown in Tables 5 and 6, for the model datasets of potato under fresh and mixed water. In Table 5, a cross validation approach was applied for the PLSR models. Calibration and validation quality of the models are presented through adjusted coefficients of determination of calibration $\left(\mathrm{R}^{2}\right.$ cal) and validation $\left(\mathrm{R}^{2}\right.$ val) and root mean square errors for calibration (RMSEC) and for validation (RMSEV), and the slopes of the linear regressions between observed and predicted values of all parameters from the calibration and validation models with observed data are shown in Table 5.

In Fig. 5 and Table 6 validation approach using fully independent data was used. Models were calibrated using datasets of (i) the spectral reflectance from 302 to $1148 \mathrm{~nm}$, (ii) selected nine spectral indices (iii) selected eight RBG indices of the image analysis in first year validated using data in second year and a cross two years to predict the measured parameters. Partial Least Square Regression creates orthogonal latent variables across the input variables and relates them to the target variables. This is a way to cope with redundancy in the input variables. The quality of the validation models is presented through adjusted coefficients of determination and the 
slope and intercept of the linear regressions between observed and predicted values measured parameters.

\section{RESULTS AND DISCUSSION}

Influence of mixed and fresh water treatments on yield, aerial biomass, SPAD value, selected normalized spectral indices and selected RGB indices of potato cultivar

The all destructively measured parameters, selected normalized spectral indices; selected RGB indices of potato cultivar were generally affected by different water quality of mixed and fresh water. Yield and aerial biomass values of potato a cross two years decreased under mixed water treatment compare to under fresh water treatment. While relative chlorophyll meter or SPAD value of potato cultivar increased under mixed water treatment compare to their values under fresh water treatment. The mean values of destructively measured parameters under fresh water treatment in two years were $605 \mathrm{~g} /$ plant for yield, $235 \mathrm{~g} / \mathrm{plant}$ for aerial biomass and 45 for SPAD value of potato cultivar. As well as the mean values of destructively measured parameters under mixed water treatment in two years were $228 \mathrm{~g} /$ plant for yield, $145 \mathrm{~g} / \mathrm{plant}$ for aerial biomass and 55 for SPAD value of potato cultivar (Table 2). The results demonstrated that the long-term accumulative of mixed water could decrease the yield and plant growth of potato cultivar. (Yadar et al., 2002) found that sewage water contents higher percentage of suspended solids, electrolytes dissolved organic matter and biochemical and chemical oxygen demand than fresh water and this leads to sewage water can directly change soil physical and hydraulic properties. The results of soil and sewage water analysis showed that there was an increasing in the values of $\mathrm{EC}, \mathrm{SAR}, \mathrm{Na}^{++}, \mathrm{Mg}^{++}, \mathrm{Ca}^{++}, \mathrm{K}^{++}, \mathrm{Cl}^{++}$, compare to their values of fresh water. Lack of productivity and the growth of potatoes are likely to be the result of different parameters such as changes in soil elements, soil physical and hydraulic properties. These results are in agreement with Kiziloglu et al. (2008), who reported that the wastewater treatment increased soil salinity, organic matter, exchangeable $\mathrm{Na}, \mathrm{K}, \mathrm{Ca}$, $\mathrm{Mg}$ and decreased soil $\mathrm{pH}$. The increase in the values of SPAD value or relative chlorophyll meter under sewage water were found in this study and these results are in agreement with Fperira et al. (2011), who 
reported that many nutrients such as nitrogen are rich in sewage water. Several investigators have reported positive effect of sewage irrigation on crop yield under short term effect. The results presented that the yield of potatoes under mixed water is lower than the yield under fresh water. These results are in agreement with Juwarker et al., 1991, who found that the continuous use of untreated sewage water for irrigation significantly reduced the yield of wheat, cotton and paddy. However, the use of primary treated sewage proved to be beneficial for both wheat and cotton. But other studies, for example, Mahida (1981) obtained higher yields of vegetable crops irrigated with untreated sewage water compared to irrigation with fresh water.

The nine normalized spectral indices values a cross two years under mixed water were higher than their values under fresh water (Table 2). The values of spectral indices were calculated based on the curves of spectral reflectance of potato cultivar under two water qualities (Fig. 1). The curves shown that, the reflectance values of potato under fresh water at visible and near infrared regions are higher than the reflectance values of potato under mixed water. This is due to the reduction in reflectance values at visible region are more affected by relative chlorophyll or other pigments and the increasing in reflectance values at near infrared region are more affected by the amount of aerial biomass (Mistele et al. 2008). As well as (Haboudane et al., 2002) reported that light reflected by vegetation in the visible region of the spectrum is predominantly influenced by the presence of chlorophyll pigments in the leaf tissues, and these relate to the leaf $\mathrm{N}$ concentration.

There were clear differences between the all spectral indices values under mixed and fresh water treatments (Table 2). Generally, RGB indices of digital image analysis presented higher values except blue (\%) under fresh water treatment compare to their values under mixed water treatment. This is due to aerial biomass of potato cultivar under fresh water is higher than aerial biomass under mixed water. On other hand the relative chlorophyll meter or SPAD values are highest under mixed water. 


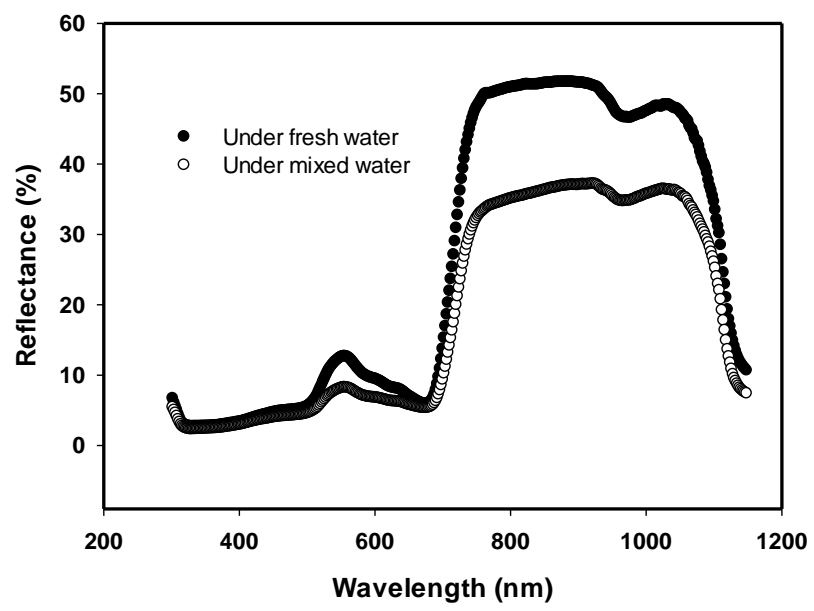

Figure 1. Spectral Reflectance Curves for potato cultivar a cross two year under fresh and mixed water treatments

\section{Contour map analysis of the hyperspectral passive data}

A contour map analysis produced the mean coefficients of determination $\left(\mathrm{R}^{2}\right)$ of the measurement data for all dual wavelength combinations as a normalized difference spectral index. The contours of the matrices of the hyperspectral passive sensor presented more distinct relationships between measure plant parameters, such as yield, aerial biomass and relative chlorophyll meter of potato cultivar with visible, near infrared wavelengths and the combination of visible and near infrared wavelengths. The contour map analysis of the relationship between the normalized difference spectral indices with (a) yield under two water qualities in first year, (b) yield under two water qualities in second year (Fig. 2). The averages of the correlation matrices resulting from the measurements at two years, indicated by the coefficients of determination $\left(\mathrm{R}^{2}\right)$ for all dual wavelengths combinations of $750-1000 \mathrm{~nm}$ as normalised difference indices for all measured parameters a cross two wheat cultivars, presented higher $\mathrm{R}^{2}$-values compared to all other two wavelength combinations (Fig. 2). This may be due 700 to $1000 \mathrm{~nm}$ being more affected by biomass and water content of plant. These findings agree with results of Gutierrez et al. (2010), who reported dual near 
infrared wavelength combinations as a normalized difference spectral index from 880 to $970 \mathrm{~nm}$ are strongly influenced by water status of plant which related to change in biomass of wheat cultivars. As well as Townsend et al. (2003) reported that the spectral reflectance in the 680 to $730 \mathrm{~nm}$ range may be related with the leaf area index.

Table 2. Minimum, maximum and mean values for yield, aerial Biomass, SPAD value, nine normalized spectral indices and eight RGB indices of potato cultivar in two years under fresh and mixed water treatments.

\begin{tabular}{|c|c|c|c|c|c|c|}
\hline \multirow{2}{*}{ Parameters } & \multicolumn{3}{|c|}{ Fresh water } & \multicolumn{3}{|c|}{ mixed water } \\
\hline & Minimum & Maximum & Average & Minimum & Maximum & Average \\
\hline Yield (g) & 325 & 900 & 605 & 95 & 525 & 228 \\
\hline Aerial Biomass (g) & 140 & 330 & 235 & 75 & 305 & 145 \\
\hline SPAD value & 37 & 53 & 45 & 49 & 60 & 55 \\
\hline HPS1 970_720 & 0.179 & 0.239 & 0.203 & 0.204 & 0.313 & 0.268 \\
\hline HPS 970_730 & 0.068 & 0.010 & 0.085 & 0.111 & 0.179 & 0.150 \\
\hline HPS 970_734 & 0.039 & 0.067 & 0.053 & 0.076 & 0.145 & 0.114 \\
\hline HPS 990_730 & 0.070 & 0.106 & 0.089 & 0.113 & 0.187 & 0.155 \\
\hline HPS 780_760 & 0.005 & 0.009 & 0.007 & 0.011 & 0.020 & 0.015 \\
\hline HPS 680_620 & -0.202 & -0.058 & -0.164 & -0.128 & -0.043 & -0.083 \\
\hline HPS 880_740 & 0.058 & 0.079 & 0.069 & 0.081 & 0.131 & 0.105 \\
\hline HPS 680_630 & -0.187 & -0.046 & -0.148 & -0.113 & -0.036 & -0.075 \\
\hline HPS 680_600 & -0.260 & -0.095 & -0.221 & -0.180 & -0.060 & -0.117 \\
\hline Plant cover $(\%)$ & 76.49 & 98.97 & 92.97 & 24.87 & 82.52 & 52.84 \\
\hline Green cover $(\%)$ & 67.79 & 95.70 & 88.46 & 13.27 & 71.37 & 40.36 \\
\hline Red pixels (\%) & 0.33 & 0.36 & 0.35 & 0.32 & 0.36 & 0.35 \\
\hline Green pixels $(\%)$ & 0.42 & 0.46 & 0.44 & 0.39 & 0.43 & 0.41 \\
\hline Blue pixels (\%) & 0.20 & 0.24 & 0.22 & 0.22 & 0.27 & 0.25 \\
\hline VARI & 0.11 & 0.21 & 0.15 & 0.06 & 0.21 & 0.12 \\
\hline NDVI & 0.08 & 0.16 & 0.11 & 0.04 & 0.13 & 0.08 \\
\hline NDVI1 & 0.18 & 0.27 & 0.23 & 0.09 & 0.23 & 0.16 \\
\hline
\end{tabular}




\section{The relationship between nine normalised difference spectral indices and yield, aerial biomass and SPAD value of potato cultivar subjected to fresh and mixed water treatments}

Across the two years measurements, nine normalised difference spectral indices were more closely related yield, aerial biomass and SPAD value of potato cultivar particular (a) under fresh and mixed water in first year, (b) under fresh and mixed water in second year, (c) under fresh and mixed water in two years. As well as six of out nine normalised difference spectral indices except HPS 780_760, HPS 680_630 and HPS 680_630 indices were significantly related to yield, aerial biomass under (d) mixed water in two years and (e) fresh water in two years. Generally, the relationships between spectral indices and SPAD value were weaker under (d) mixed water in two years and (e) fresh water in two years than under (a) fresh and mixed water in first year, (b) fresh and mixed water in second year, (c) fresh and mixed water in two years. The obtained coefficients of determination $\left(\mathrm{R}^{2}\right)$ are shown in Table 3. Statistically significant relationships between all spectral reflectance indices derived from visible, near infrared region and combination between them was found for yield ( $\mathrm{R}^{2}$ values ranging from $0.16^{*}$ to $\left.0.87^{* * *}\right)$, aerial biomass $\left(\mathrm{R}^{2}\right.$ values ranging from $0.15^{*}$ to $\left.0.80^{* * *}\right)$ and $\mathrm{SPAD}$ values $\left(\mathrm{R}^{2}\right.$ values ranging from $0.16^{*}$ to $0.86^{* * *}$ ) as shown in Table 3 . Generally, the normalized spectral index of $\left(\mathrm{R}_{970}-\mathrm{R}_{730}\right) /\left(\mathrm{R}_{970}+\mathrm{R}_{730}\right)$ in figure 3 and spectral index $\left(R_{990}-R_{730}\right) /\left(R_{990}+R_{730}\right)$ showed the highest coefficients of determination for the measured parameters a cross different measurements time and treatments.

The results demonstrated that the selected nine spectral reflectance indices (Table 3) were apparently useful for estimating yield, aerial biomass and SPAD value of potato cultivar at tuber bulking growth stage. Similar to our results, Prasad et al. (2007) reported that the normalized difference vegetation index (NDVI) has been very useful in predicting crop yield and assessing yield models using various approaches from simple integration to complex transformation. As well as these results are in agreement with Lobos et al. (2014), who reported that the $\left(\mathrm{R}_{830}-\right.$ $\left.\mathrm{R}_{660}\right) /\left(\mathrm{R}_{830}+\mathrm{R}_{660}\right)$ and the $\left(\mathrm{R}_{970}-\mathrm{R}_{920}\right) /\left(\mathrm{R}_{970}+\mathrm{R}_{920}\right)$ presented well 
relationships $\left(\mathrm{R}^{2}\right.$ values of 0.62 and 0.66$)$ with the grain yield of wheat cultivars under drought stress conditions.
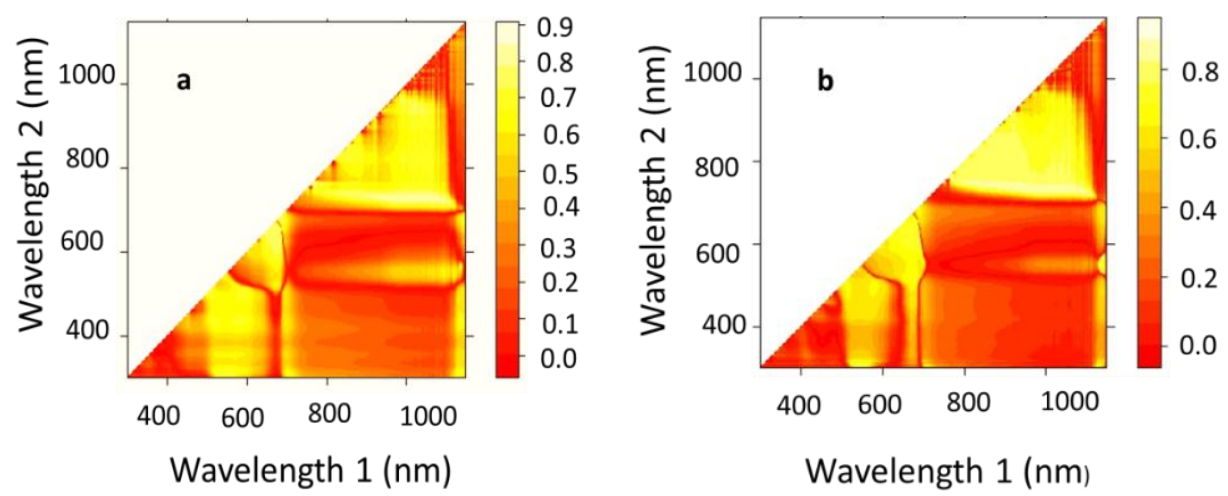

Figure 2. Correlation matrices (contour maps) showing the coefficients of determination $\left(R^{2}\right)$ for all dual wavelength combinations in the 302-1148 $\mathrm{nm}$ range (as a normalised difference index) of the hyperspectral passive reflectance sensing with (a) yield under two water qualities in first year, (b) yield under two water qualities in second year.

The relationship between eight RGB with yield, aerial biomass and SPAD value of potato cultivar subjected to fresh and mixed water treatments

Across the two years measurements, eight RGB were related to yield, aerial biomass and SPAD value of potato cultivar particular (a) under fresh and mixed water in first year, (b) under fresh and mixed water in second year, (c) under fresh and mixed water in two years. The plant cover (\%), green cover (\%) and blue pixel (\%) presented stronger relationships with yield; aerial biomass and SPAD value of potato cultivar compare to other RGB indices (Table 4). Generally, the relationships between spectral indices and SPAD value were weaker under (d) mixed water in two years and (e) fresh water in two years than under (a) fresh and mixed water in first year, (b) fresh and mixed water in second year and (c) fresh and mixed water in two years. The obtained coefficients of determination $\left(\mathrm{R}^{2}\right)$ are shown in Table 4. Statistically significant 
relationships between all RGB between them was found for yield $\left(\mathrm{R}^{2}\right.$ values ranging from $0.15^{*}$ to $\left.0.85^{* * *}\right)$, aerial biomass $\left(\mathrm{R}^{2}\right.$ values ranging from $0.15^{*}$ to $\left.0.74^{* * *}\right)$ and $\mathrm{SPAD}$ values $\left(\mathrm{R}^{2}\right.$ values ranging from $0.18^{*}$ to $0.70^{* * *}$ ). Similar our results, Kipp et al. (2014) found that VARI is related to biomass of wheat cultivars. Sugarcane leaf images are captured by a portable camera and then relationships between nitrogen content and leaf colors in red $(R)$, green $(G)$, blue $(B)$ and near infrared (IR) are examined. The terns R, G, B, G/B, G/R, R/B and ((IR-R)/ (IR+R)) had the significant relationship with nitrogen concentration in the sugarcane leaves (Pity et al., 2012).

There was a linear relationship between plant cover (\%) and yield, aerial biomass, SPAD value of potato cultivar until there was $80 \%$ plant cover (\%). Saturation effects appeared after there were $80 \%$ plant covers. These results agree with other studies by Paruelo et al. (2000), who found that the curvilinear relationships between the percentage of plant covers (\%) and green grass biomass $(\mathrm{r}=0.91)$ and strong saturation effects were close to $90 \%$ total plant covers (\%). Lee and Lee (2013) found that the curvilinear relationships of the canopy cover, derived from the colour digital camera image analysis, were best related to the measured shoot nitrogen accumulation $\left(R^{2}=0.87\right)$, shoot dry weight $\left(R^{2}=0.71\right)$ and leaf area index $\left(\mathrm{R}^{2}=0.88\right)$ at varying nitrogen fertilization levels, and saturation effects became apparent close to $80 \%$ of the canopy cover.

\section{Partial least squares regression analysis to predict the different measurement variables}

In Table 5, the quality of the PLSR models 7- fold cross-validation is represented by adjusted coefficients of determination of calibration $\left(\mathrm{R}^{2}\right.$ cal) and validation ( $\left.\mathrm{R}^{2} \mathrm{val}\right)$, root mean square errors (RMSE cal and val), and the slope of the linear regressions for calibration and validation models for (a) fresh and mixed water in first year, (b) fresh and mixed water in second year, (c) fresh and mixed water in two years, (d) mixed water in two years and (e) under fresh water in two years. Across all calibration data set formations, the significant coefficients of determination varied from $0.39 * * *$ to $0.89 * * *$ for all measured parameters. 
Table 3. Coefficients of determination of the relationship between nine normalized spectral indices with yield, aerial biomass, SPAD value of potato cultivar subjected to fresh and mixed water treatments. Coefficients of determination of the relationship between them presented through; (a) under fresh and mixed water in first year, (b) under fresh and mixed water in second year, (c) under fresh and mixed water in two years, (d) under mixed water in two years and (e) under fresh water in two years.

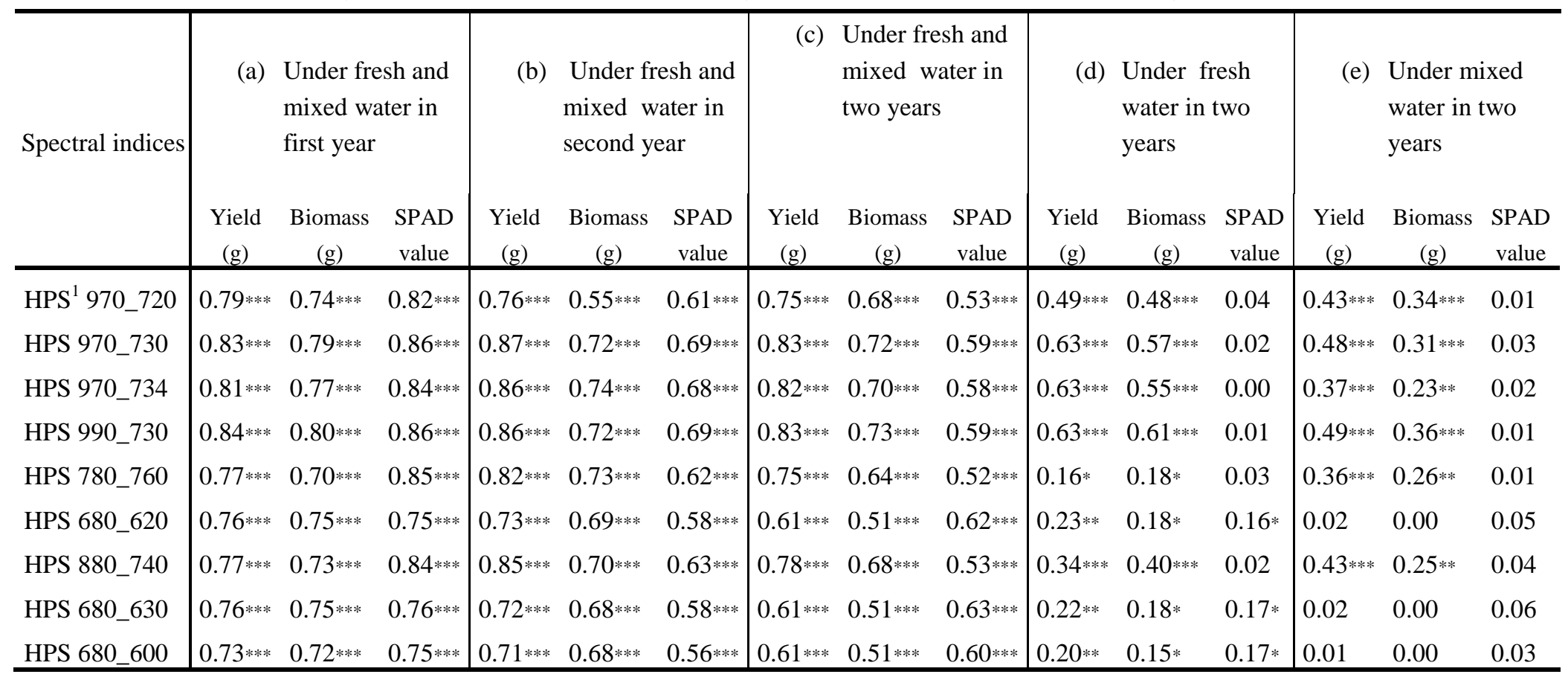

$*, * *, * * *$ Statistically significant at $\mathrm{P} \leq 0.05 ; \mathrm{P} \leq 0.01$ and $\mathrm{P} \leq 0.001$, respectively 

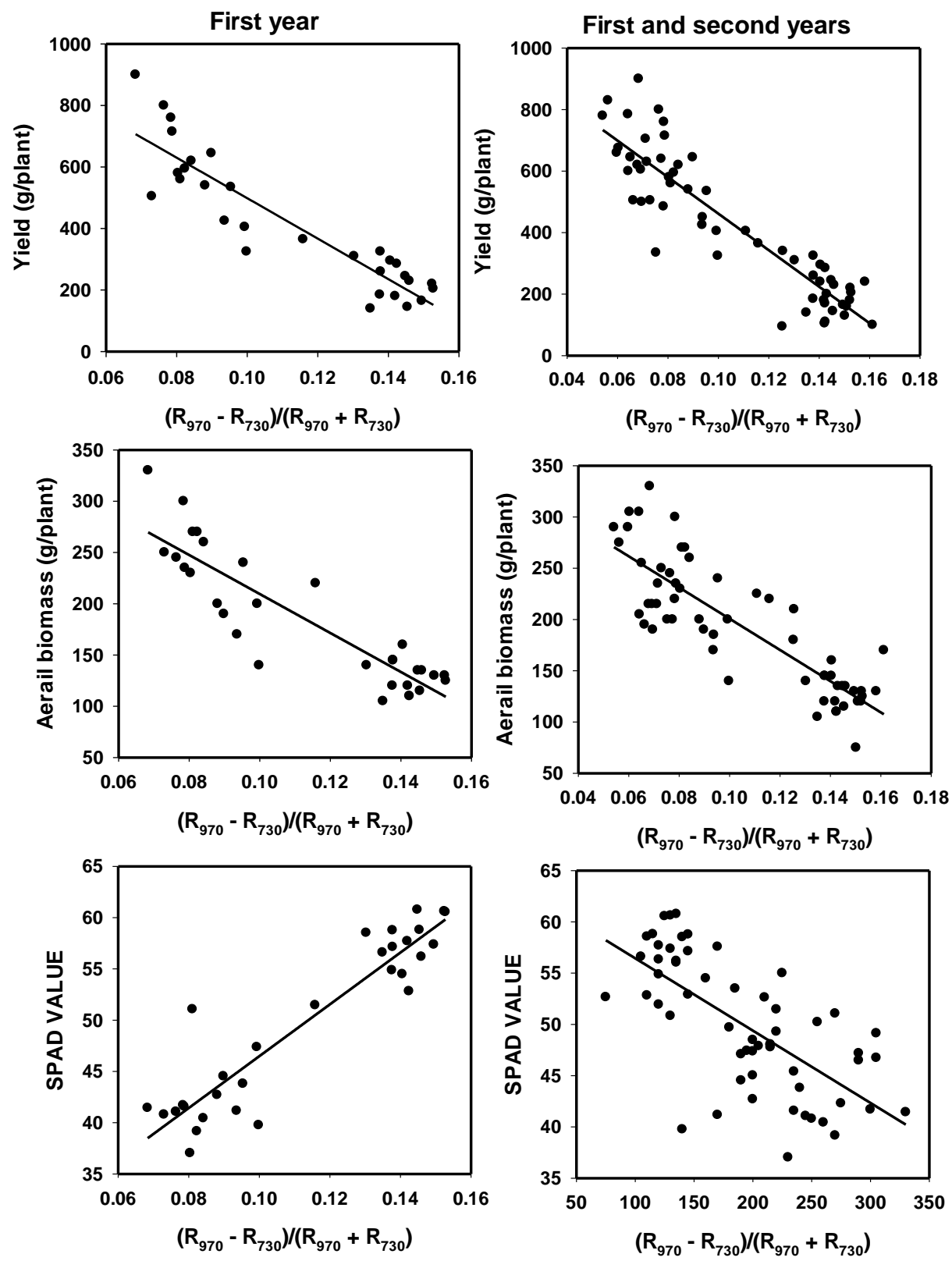

Figure 3. The relationship between the spectral index $\left(\mathbf{R}_{970}-\mathbf{R}_{\mathbf{7 3 0}}\right) /$ $\left(\mathbf{R}_{970}+\mathbf{R}_{\mathbf{7 3 0}}\right)$ and yield, aerial biomass, SPAD value of potato cultivar subjected to fresh and mixed water treatments in first year and across two years. Statistical information is given in Table 4. 
Table 4. Coefficients of determination of the relationship between eight RGB indices with yield, aerial biomass, SPAD value of potato cultivar subjected to fresh and mixed water treatments. Coefficients of determination of the relationship between them presented through; (a) under fresh and mixed water in first year, (b) under fresh and mixed water in second year, (c) under fresh and mixed water in two years, (d) under mixed water in two years and

\begin{tabular}{|c|c|c|c|c|c|c|c|c|c|c|c|c|c|c|c|}
\hline \multirow[t]{2}{*}{ RGB indices } & \multicolumn{3}{|c|}{$\begin{array}{l}\text { (a) Under fresh and mixed } \\
\text { water in first year }\end{array}$} & \multicolumn{3}{|c|}{$\begin{array}{l}\text { (b) Under fresh and mixed } \\
\text { water in second year }\end{array}$} & \multicolumn{3}{|c|}{$\begin{array}{c}\text { (c) Under fresh and mixed } \\
\text { water in two years }\end{array}$} & \multicolumn{3}{|c|}{$\begin{array}{c}\text { (d) Under mixed water } \\
\text { in two years }\end{array}$} & \multicolumn{3}{|c|}{$\begin{array}{c}\text { (e) Under fresh water in } \\
\text { two years }\end{array}$} \\
\hline & $\begin{array}{l}\text { Yield } \\
(\mathrm{g}) \\
\end{array}$ & $\begin{array}{c}\text { Biomass } \\
(\mathrm{g}) \\
\end{array}$ & $\begin{array}{l}\text { Spad } \\
\text { value }\end{array}$ & $\begin{array}{l}\text { Yield } \\
(\mathrm{g})\end{array}$ & $\begin{array}{c}\text { Biomass } \\
\text { (g) }\end{array}$ & $\begin{array}{l}\text { Spad } \\
\text { value }\end{array}$ & $\begin{array}{c}\text { Yield } \\
(\mathrm{g}) \\
\end{array}$ & $\begin{array}{c}\text { Biomass } \\
(\mathrm{g}) \\
\end{array}$ & $\begin{array}{l}\text { Spad } \\
\text { value }\end{array}$ & $\begin{array}{l}\text { Yield } \\
(\mathrm{g})\end{array}$ & $\begin{array}{c}\text { Biomass } \\
(\mathrm{g}) \\
\end{array}$ & $\begin{array}{l}\text { Spad } \\
\text { value }\end{array}$ & $\begin{array}{l}\text { Yield } \\
(\mathrm{g})\end{array}$ & $\begin{array}{c}\text { Biomass } \\
(\mathrm{g}) \\
\end{array}$ & $\begin{array}{l}\text { Spad } \\
\text { value }\end{array}$ \\
\hline Plant cover $(\%)$ & $0.74 * * *$ & $0.74 * * *$ & $0.68 * * *$ & $0.85 * * *$ & $0.72 * * *$ & $0.62 * * *$ & $0.80 * * *$ & $0.71 * * *$ & $0.57 * * *$ & $0.18 *$ & $0.26^{* *}$ & 0.10 & $0.46 * * *$ & $0.44 * * *$ & 0.04 \\
\hline Green cover $(\%)$ & $0.76 * * *$ & $0.73 * * *$ & $0.70 * * *$ & $0.82 * * *$ & $0.71 * * *$ & $0.61 * * *$ & $0.80 * * *$ & $0.70 * * *$ & $0.57 * * *$ & 0.14 & $0.22 * * *$ & 0.04 & $0.40 * * *$ & $0.41 * * *$ & 0.06 \\
\hline Red pixels (\%) & 0.11 & 0.07 & $0.18 *$ & $0.19 *$ & $0.32 * * *$ & 0.04 & 0.03 & 0.03 & 0.05 & 0.07 & 0.06 & $0.26 * *$ & 0.02 & 0.15 & 0.07 \\
\hline Green pixels $(\%)$ & $0.67 * * *$ & $0.63 * * *$ & $0.54 * * *$ & $0.82 * * *$ & $0.68 * * *$ & $0.54 * * *$ & $0.67 * * *$ & $0.58 * * *$ & $0.33 * * *$ & 0.11 & 0.06 & $0.18 *$ & $0.27 * *$ & $0.27 * *$ & 0.11 \\
\hline Blue pixels $(\%)$ & $0.51 * * *$ & $0.47 * * *$ & $0.57 * * *$ & $0.77 * * *$ & $0.51 * * *$ & $0.66 * * *$ & $0.63 * * *$ & $0.47 * * *$ & $0.43 * * *$ & 0.02 & 0.01 & 0.01 & 0.17 & 0.04 & 0.09 \\
\hline VARI & 0.10 & 0.13 & 0.08 & $0.65 * * *$ & $0.70 * * *$ & $0.36 * * *$ & $0.40 * * *$ & $0.43 * * *$ & 0.10 & 0.11 & 0.10 & $0.55 * * *$ & 0.11 & $0.27 * *$ & 0.14 \\
\hline NDVI & $0.28 * *$ & $0.27 * *$ & 0.14 & $0.74 * * *$ & $0.72 * * *$ & $0.45 * * *$ & $0.50 * * *$ & $0.50 * * *$ & 0.13 & 0.10 & 0.10 & $0.57 * * *$ & 0.14 & $0.31 * * *$ & $0.15^{*}$ \\
\hline NDVI1 & $0.31 * * *$ & $0.33 * * *$ & $0.18 *$ & $0.63 * * *$ & $0.34 * * *$ & $0.60 * * *$ & $0.49 * * *$ & $0.33 * * *$ & $0.44 * * *$ & 0.02 & 0.00 & 0.04 & $0.15^{*}$ & 0.02 & 0.07 \\
\hline
\end{tabular}

(e) under fresh water in two years.

$*, * *, * *$ Statistically significant at $\mathbf{P} \leq 0.05 ; \mathrm{P} \leq 0.01$ and $\mathrm{P} \leq 0.001$, respectively 


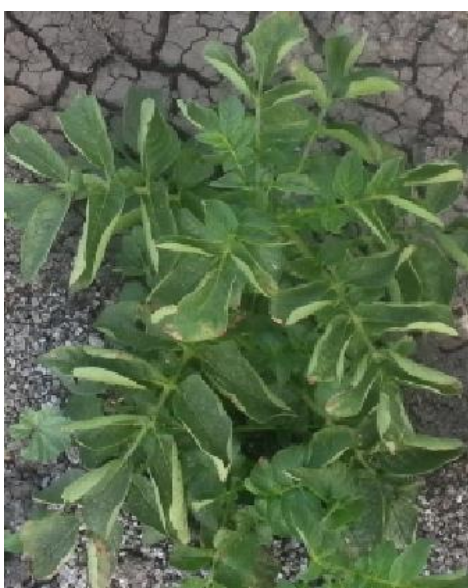

(a)

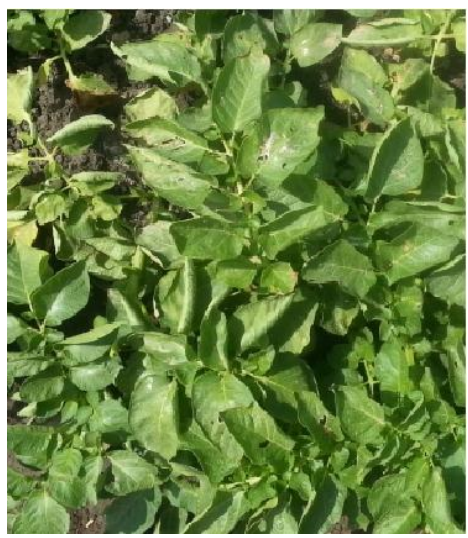

(c)

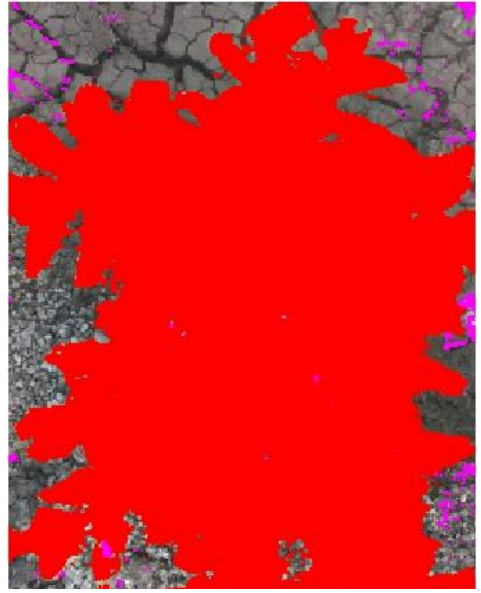

(b)

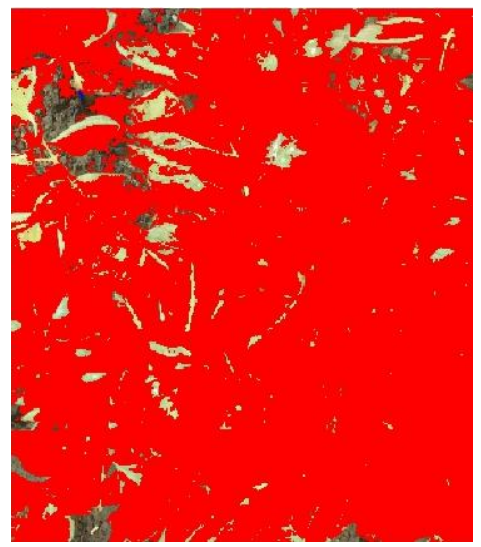

(d)

Figure 4. Analysis of the amount of green-red-blue pixels in the digital images of a potato plant: left side (a) and (c) original digital image and right side (b) and (d) images were converted to the HSB (hue, saturation and lightness/luminance) color space to select (b) plant cover (\%) and (d) green cover $(\%)$ at tuber bulking growth stage.

Across all validation data set formations, the coefficients of determination varied from $0.24 * * *$ to $0.86^{* * *}$ for all measured parameters. Across all calibration and validation data set formations, the RMSE varied from 63 to $132 \mathrm{~g} /$ plant for potatoes yield and 1.9 to 4.5 for SPAD values. The highest slopes for the calibration and validation data sets were 0.89 and 0.87 , respectively, across all data (Table 5). 
Table 5. Calibration ( $\mathbf{R}^{2}$ cal, RMSEC and Slope cal) and 7-fold cross-validation ( $\mathbf{R}^{2} \mathbf{v a l}$, RMSEV and Slope val) statistics of partial least square regression models of (a) spectral reflectance $(302-1148 \mathrm{~nm})$, (b) nine spectral indices of the hyperspectral active reflectance sensor as well as (c) Eight RGB indices from digital image analysis with yield, biomass and SPAD value of potato cultivars under fresh water (FW) and mixed water (MW) in first year, fresh and mixed water in second year, fresh and mixed water in two years, mixed water in two years and under fresh water in two years.

\begin{tabular}{|c|c|c|c|c|c|c|c|c|c|c|c|c|c|c|c|c|}
\hline \multirow[t]{2}{*}{$\begin{array}{c}\text { Measured } \\
\text { parameters }\end{array}$} & \multirow[t]{2}{*}{\begin{tabular}{|c} 
Statistical \\
Parameters
\end{tabular}} & \multicolumn{5}{|c|}{$\begin{array}{l}\text { Spectral reflectance }(302-1148 \\
\mathrm{nm})\end{array}$} & \multicolumn{5}{|c|}{ (b) Nine spectral indices } & \multicolumn{5}{|l|}{ (c) } \\
\hline & & $\begin{array}{l}\text { FW and } \\
\text { MW in } \\
\text { first } \\
\text { year }\end{array}$ & \begin{tabular}{|l} 
FW and \\
MW \\
in \\
second \\
year \\
\end{tabular} & \begin{tabular}{|l|} 
FW and \\
MW \\
in two \\
years \\
\end{tabular} & $\begin{array}{l}\text { MW in } \\
\text { two } \\
\text { years }\end{array}$ & $\begin{array}{l}\text { FW in } \\
\text { two } \\
\text { years }\end{array}$ & $\begin{array}{l}\text { FW and } \\
\text { MW in } \\
\text { first } \\
\text { year }\end{array}$ & $\begin{array}{l}\text { FW and } \\
\text { MW } \\
\text { in } \\
\text { second } \\
\text { year } \\
\end{array}$ & \begin{tabular}{|l|} 
FW and \\
MW \\
in two \\
years \\
\end{tabular} & $\begin{array}{l}\text { MW in } \\
\text { two } \\
\text { years }\end{array}$ & $\begin{array}{l}\text { FW in } \\
\text { two } \\
\text { years }\end{array}$ & $\begin{array}{l}\text { FW and } \\
M W \text { in } \\
\text { first } \\
\text { year }\end{array}$ & \begin{tabular}{|l|} 
FW and \\
MW \\
in \\
second \\
year \\
\end{tabular} & $\begin{array}{l}\text { FW and } \\
\text { MW } \\
\text { in two } \\
\text { years }\end{array}$ & \begin{tabular}{|l} 
MW \\
in two \\
years
\end{tabular} & $\begin{array}{l}\text { FW in } \\
\text { two } \\
\text { years }\end{array}$ \\
\hline \multirow{6}{*}{ Yield } & $\mathbf{R}^{2}$ cal & $0.87 * * *$ & $0.89 * * *$ & $0.86 * * *$ & $0.47 * * *$ & $0.69 * * *$ & $0.84 * * *$ & $0.88 * * *$ & $0.85 * * *$ & $0.53 * * *$ & $0.63 * * *$ & $0.72 * * *$ & $0.79 * * *$ & $0.76 * * *$ & $0.39 * *$ & $0.25 * *$ \\
\hline & $\mathbf{R}^{2}$ val & $0.80 * * *$ & $0.84 * * *$ & $0.83 * * *$ & $0.34 * *$ & $0.52 * * *$ & $0.81 * * *$ & $0.82 * * *$ & $0.84 * * *$ & $0.34 * *$ & $0.59 * * *$ & $0.71 * * *$ & $0.76 * * *$ & $0.74 * * *$ & $0.37 * *$ & 0.09 \\
\hline & RMSEC & 78.29 & 82.92 & 84.79 & 71.71 & 76.47 & 85.9 & 86.85 & 88.46 & 67.54 & 83.28 & 112 & 112.29 & 111.55 & 63.14 & 118.6 \\
\hline & RMSEV & 92.11 & 112.1 & 96.18 & 85.68 & 94.97 & 94.6 & 95.64 & 91.69 & 79.1 & 95.91 & 120 & 120.44 & 118.58 & 66.29 & 132.2 \\
\hline & Slope cal & 0.86 & 0.89 & 0.86 & 0.47 & 0.69 & 0.84 & 0.88 & 0.85 & 0.53 & 0.63 & 0.72 & 0.79 & 0.76 & 0.39 & 0.25 \\
\hline & Slope val & 0.83 & 0.86 & 0.84 & 0.32 & 0.57 & 0.82 & 0.87 & 0.84 & 0.44 & 0.57 & 0.71 & 0.78 & 0.75 & 0.37 & 0.17 \\
\hline \multirow{6}{*}{ Biomass } & $\mathbf{R}^{2}$ cal & $0.82 * * *$ & $0.81 * * *$ & $0.79 * * *$ & $0.90 * * *$ & $0.68 * * *$ & $0.79 * * *$ & $0.75 * * *$ & $0.74 * * *$ & $0.65 * * *$ & $0.58 * * *$ & $0.70 * * *$ & $0.72 * * *$ & $0.69 * * *$ & $0.41 * *$ & $0.24 * *$ \\
\hline & $\mathbf{R}^{2}$ val & $0.75 * * *$ & $0.75 * * *$ & $0.73 * * *$ & $0.55 * * *$ & $0.45 * *$ & $0.80 * * *$ & $0.78 * * *$ & $0.71 * * *$ & $0.39 * *$ & $0.45 * * *$ & $0.66 * * *$ & $0.71 * * *$ & $0.68 * * *$ & $0.24 * *$ & $0.26 * *$ \\
\hline & RMSEC & 27.32 & 31.75 & 29.47 & 16.81 & 25.85 & 29.26 & 35.53 & 31.67 & 31 & 29.26 & 34.5 & 38.1 & 37.26 & 32.2 & 38.79 \\
\hline & RMSEV & 31.92 & 36.83 & 34.43 & 38.17 & 33.31 & 31.11 & 38.29 & 33.27 & 40.65 & 33.1 & 36.9 & 40.72 & 38.67 & 38.52 & 41.2 \\
\hline & Slope cal & 0.81 & 0.81 & 0.79 & 0.9 & 0.67 & 0.79 & 0.75 & 0.74 & 0.65 & 0.58 & 0.7 & 0.72 & 0.69 & 0.41 & 0.24 \\
\hline & Slope val & 0.77 & 0.77 & 0.76 & 0.6 & 0.56 & 0.77 & 0.73 & 0.73 & 0.5 & 0.51 & 0.68 & 0.7 & 0.69 & 0.35 & 0.19 \\
\hline \multirow{6}{*}{ Spad } & $\mathbf{R}^{2}$ cal & $0.85 * * *$ & $0.72 * * *$ & $0.81 * * *$ & $0.56 * * *$ & $0.72 * * *$ & $0.86 * * *$ & $0.68 * * *$ & $0.73 * * *$ & $0.49 * *$ & $0.24 * *$ & $0.67 * * *$ & $0.66 * * *$ & $0.61 * * *$ & $0.18 *$ & $0.26 * *$ \\
\hline & $\mathbf{R}^{2}$ val & $0.81 * * *$ & $0.62 * * *$ & $0.68 * * *$ & $0.38 * *$ & 0.00 & $0.86 * * *$ & $0.66 * * *$ & $0.70 * * *$ & $0.27 *$ & 0.15 & $0.63 * * *$ & $0.60 * * *$ & $0.57 * * *$ & 0.00 & 0.03 \\
\hline & RMSEC & 3.14 & 2.09 & 2.8 & 2.18 & 1.91 & 2.98 & 2.24 & 3.31 & 2.35 & 3.18 & 4.61 & 2.28 & 3.94 & 2.93 & 3.36 \\
\hline & RMSEV & 3.74 & 2.52 & 3.65 & 2.5 & 4.46 & 3.29 & 2.43 & 3.56 & 2.9 & 3.54 & 4.92 & 2.64 & 4.26 & 3.6 & 3.95 \\
\hline & Slope cal & 0.85 & 0.72 & 0.8 & 0.56 & 0.72 & 0.86 & 0.68 & 0.73 & 0.49 & 0.24 & 0.67 & 0.66 & 0.61 & 0.18 & 0.26 \\
\hline & Slope val & 0.81 & 0.66 & 0.76 & 0.48 & 0.12 & 0.85 & 0.65 & 0.71 & 0.37 & 0.16 & 0.66 & 0.6 & 0.58 & 0.01 & 0.14 \\
\hline
\end{tabular}

$*, * *, * * *$ Statistically significant at $\mathbf{P} \leq 0.05 ; \mathbf{P} \leq 0.01$ and $\mathbf{P} \leq 0.001$, respectively 
The use of the full spectral range from 302 to $1148 \mathrm{~nm}$, nine spectral indices and eight RGB indices for the PLSR analysis increased the accuracy of the estimates of the measured parameters of potato cultivar (Table 5) compared with the use of the normalised difference spectral indices (Table 3). The PLSR technique allowed identification of optimized models and is considered the state-of-the art technique enabling a high efficiency in searching for optimized relationships. Simple linear, polynomial, or exponential functions are used to model the relationship between biophysical parameters and vegetation indices. Alternatively, non-linear regression techniques, such as Support Vector Regression (SVR), have been applied.

Also the three models were calibrated depend on data of first year of fresh and mixed treatments of potato cultivar. Calibration functions were validated with independent data measured in second year and across two year with different treatments. For the model of PLSR based on spectral data range from 302 to $1148 \mathrm{~nm}$ for predict grain yield, the coefficients of determination varied from $0.39 * *$ to $0.86^{* * *}$ and the slope of the linear regression varied from 0.41 to 0.84 . For the model of PLSR based on nine spectral indices for predict grain yield, the coefficients of determination varied from $0.54 * *$ to $0.87 * * *$ and the slope of the linear regression varied from 0.33 to 0.78 . As well as for the model of PLSR based on eight RGB indices for predict grain yield, the coefficients of determination varied from 0.16 to $0.79 * * *$ and the slope of the linear regression varied from 0.14 to 0.94 .

The results demonstrated that the three models (Table 6 and figure5) were apparently useful for estimating the yield, aerial biomass and spad value of potato cultivar under fresh and mixed water treatments. These results agree with Sharabian et al. (2014), who found that strong relationships existed between predicted and observed values for a validation dataset of grain yield $\left(\mathrm{R}^{2}=0.87, \mathrm{RMSE}=301\right)$ and SPAD values $\left(\mathrm{R}^{2}=0.84\right.$, RMSE $=1.94)$. Elsayed et al. (2015 b) found that PLSR models could improve the assessment of pod yield in peanut cultivars. 
Table 6. Partial least square models of spectral reflectance $(302-1148 \mathrm{~nm})$, nine spectral indices and eight RGB indices from digital image analysis with yield, aerial biomass and SPAD value of potato cultivars. Calibration functions were validated with independent data measured on the indicated prediction dates. Coefficients of determination, slopes and intercepts of these linear validation functions between observed and predicted values of measured parameters are shown. Significance levels are shown.

\begin{tabular}{|c|c|c|c|c|c|c|c|c|c|c|}
\hline \multirow[t]{2}{*}{$\begin{array}{l}\text { Predicted } \\
\text { data }\end{array}$} & \multirow[t]{2}{*}{ Parameters } & \multicolumn{3}{|c|}{$\begin{array}{l}\text { Calibrated data based on } \\
\text { spectral reflectance }(302-1148 \\
\text { nm) of fresh and mixed water } \\
\text { treatments of first year }\end{array}$} & \multicolumn{3}{|c|}{$\begin{array}{l}\text { Calibrated data based on } \\
\text { nine spectral indices of fresh and } \\
\text { mixed water treatments of first } \\
\text { year }\end{array}$} & \multicolumn{3}{|c|}{$\begin{array}{l}\text { Calibrated data based on eight } \\
\text { RGB indices from digital image } \\
\text { analysis of fresh and mixed } \\
\text { water treatments of first year }\end{array}$} \\
\hline & & $\mathrm{r}^{2}$ & $\mathrm{a}$ & $\mathrm{b}$ & $\mathrm{r}^{2}$ & $\bar{a}$ & $\mathrm{~b}$ & $\mathrm{r}^{2}$ & $\bar{a}$ & $\mathrm{~b}$ \\
\hline $\begin{array}{l}\text { a } \\
\mathbf{b} \\
\mathbf{c} \\
\mathbf{d}\end{array}$ & Yield & $\begin{array}{l}0.86 * * * \\
0.80 * * * \\
0.39 * * * \\
0.68 * * *\end{array}$ & $\begin{array}{l}0.75 \\
0.84 \\
0.60 \\
0.41\end{array}$ & $\begin{array}{l}133.94 \\
119.77 \\
116.18 \\
355.30\end{array}$ & $\begin{array}{l}0.87 * * * \\
0.84 * * * \\
0.54 * * * \\
0.57 * * *\end{array}$ & $\begin{array}{l}0.87 \\
0.86 \\
0.65 \\
0.33\end{array}$ & $\begin{array}{l}21.33 \\
84.88 \\
52.28 \\
388.7 \\
\end{array}$ & $\begin{array}{l}0.79 * * * \\
0.75 * * * \\
0.39 * * \\
0.16\end{array}$ & $\begin{array}{l}0.83 \\
0.80 \\
0.94 \\
0.14\end{array}$ & $\begin{array}{l}49.16 \\
71.30 \\
0.17 \\
496.4 \\
\end{array}$ \\
\hline $\begin{array}{l}\mathbf{a} \\
\mathbf{b} \\
\mathbf{c} \\
\mathbf{d}\end{array}$ & Biomass & $\begin{array}{l}0.72 * * * \\
0.73 * * * \\
0.46 * * \\
0.61 * * *\end{array}$ & $\begin{array}{l}0.69 \\
0.80 \\
0.28 \\
0.32 \\
\end{array}$ & $\begin{array}{l}62.47 \\
48.84 \\
94.62 \\
164.22 \\
\end{array}$ & $\begin{array}{l}0.75 * * * \\
0.68 * * * \\
0.35 * * \\
0.12\end{array}$ & $\begin{array}{l}0.76 \\
0.74 \\
0.23 \\
0.14 \\
\end{array}$ & $\begin{array}{l}31.73 \\
41.47 \\
176.9 \\
102.2 \\
\end{array}$ & $\begin{array}{l}0.72 * * * \\
0.70 * * * \\
0.41 * * \\
0.24 * *\end{array}$ & $\begin{array}{l}0.82 \\
0.76 \\
0.50 \\
0.16\end{array}$ & $\begin{array}{l}22.19 \\
38.61 \\
55.18 \\
196.5 \\
\end{array}$ \\
\hline $\begin{array}{l}\mathbf{a} \\
\mathbf{b} \\
\mathbf{c} \\
\mathbf{d}\end{array}$ & SPAD value & $\begin{array}{l}0.71 * * * \\
0.64 * * * \\
0.08 \\
0.00\end{array}$ & $\begin{array}{l}1.60 \\
0.99 \\
0.24 \\
0.03\end{array}$ & $\begin{array}{l}-30.43 \\
-1.39 \\
42.91 \\
41.20\end{array}$ & $\begin{array}{l}0.69 * * * \\
0.03 \\
0.61 * * * \\
0.01\end{array}$ & $\begin{array}{l}1.91 \\
0.11 \\
1.03 \\
-0.13\end{array}$ & $\begin{array}{l}-44.8 \\
37.70 \\
-3.30 \\
65.03\end{array}$ & $\begin{array}{l}0.61 \text { *** } \\
0.03 \\
0.57 * * * \\
0.06\end{array}$ & $\begin{array}{l}1.53 \\
0.10 \\
0.65 \\
-0.22\end{array}$ & $\begin{array}{l}-25.4 \\
39.78 \\
17.14 \\
69.88\end{array}$ \\
\hline
\end{tabular}

(a) data of spectral reflectance or spectral indices or RGB indices of fresh and mixed water treatments in second year; (b) data of spectral reflectance or spectral indices or RGB indices of fresh and mixed water treatments in two years; (c) data of spectral reflectance or spectral indices or RGB indices of mixed water treatment in two years and (d) data of spectral reflectance or spectral indices or RGB indices of mixed water treatment in two years. 

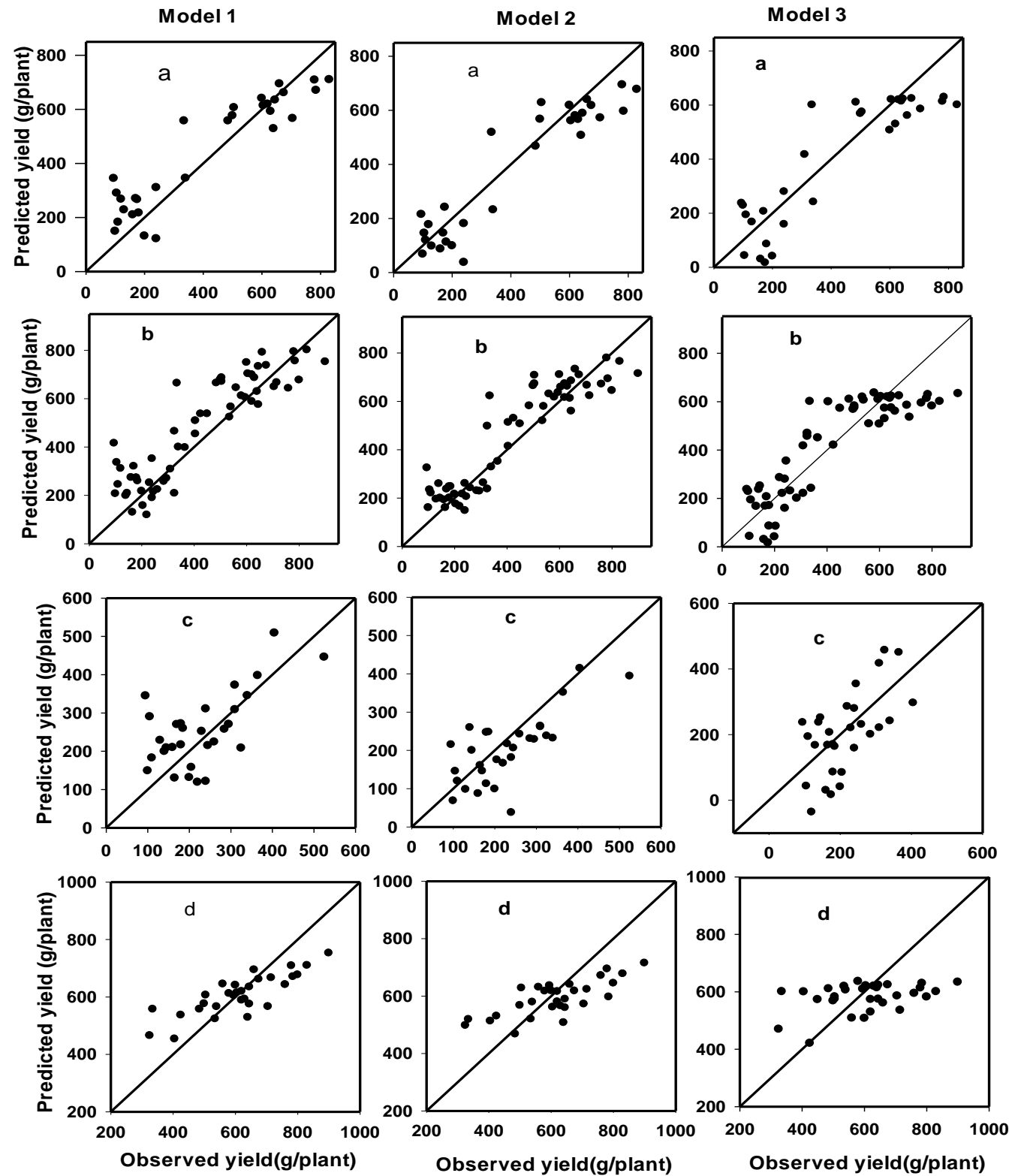

Figure 5. Scatter plots and linear regressions of three models; model 1 of PLSR based on spectral reflectance $(302-1148 \mathrm{~nm})$, model 2 of PLSR based on nine spectral indices and model 3 of PLSR based on eight RGB indices between observed and predicted values of (a) yield under fresh and mixed water treatments in second year; (b) yield under fresh and mixed water treatments in two years; (c) yield under mixed water treatment in two years and (d) yield under mixed water treatment in two years. Statistical information is given in Table 6. 


\section{CONCLUSIONS}

The results show that the models developed from the normalised difference spectral indices, RGB indices of digital images analysis and PLSR analysis reliably assessed the yield, biomass and relative chlorophyll meter. Partial least square regression models of three models based on (i) the spectral reflectance from 302 to $1148 \mathrm{~nm}$, (ii) selected nine spectral indices and (iii) selected eight RBG indices of the images analysis potentially improve non-invasive measurements the yield, aerial biomass and relative chlorophyll meter of potato cultivar compared with normalised difference spectral indices and RGB indices analysis. Further work should also investigate the accumulative of heavy metals in water, soil and plant in this area of study.

\section{REFERENCES}

Adamsen, F. G., Pinter, J. P., Barnes, M. E., LaMorte, L. R., Wall, W. G., Leavitt, W. S., Kimball., A. B., (1999). Measuring wheat senescence with a digital camera. Crop. Sci. 39, 719-724.

Allam A.E. and Negm, A.M., (2013). Agricultural drainage water quality analysis and its suitability for direct reuse in irrigation: case study: Kafr El-Sheikh governorate, Egypt", Seventeenth International Water Technology Conference, IWTC17 Istanbul, 5-7 November, 2013.

Auearunyawat, P., Kasetkasem S.A. (2012). An Automatic Nitrogen Estimation Method inSugarcane Leaves Using Image Processing Techniques\| International Conference on Agricultural, Environment and Biological Sciences (ICAEBS'2012) May 26-27.

El-Hendawy, S., Al-Suhaibani, N., Salem, A., Ur Rehman, S., Schmidhalter, U. (2015). Spectral reflectance indices as a rapid nondestructive phenotyping tool for estimating different morphophysiological traits of contrasting spring wheat germplasms under arid conditions. Turk. J. Agric. For. 39: 572-587.

Elsayed, S., Elhoweity, M., Schmidhalter, U. (2015a). Normalized difference spectral indices and partial least squares regression to 
assess the yield and yield components of peanut. Aust. J. Crop Sci. 10: $976-986$

Elsayed, S., Rischbeck, P., Schmidhalter, U. (2015b). Comparing the performance of active and passive reflectance sensors to assess the normalized relative canopy temperature and grain yield of droughtstressed barley cultivars. Field Crop Res. 177:148-160.

El-Shikha, D.M., Waller, P., Hunsaker, D., Clarke, T., Barnes E. (2007). Ground-based remote sensing for assessing water and nitrogen status of broccoli. Agr Water Mange. 92:183-193.

Erdle, K., Mistele, B., Schmidhalter, U. (2011). Comparison of active and passive spectral sensors in discriminating biomass parameters and nitrogen status in wheat cultivars. Field Crops Res. 124: 74-84.

Fpereira, B.F., He, Z.L., Silva, M.S., Herpin, U., Nogueira, S.F., Montes, C.R., Melfi, A.J. (2011). Reclaimed wastewater: Impact on soil-plant system under tropical conditions. J. Hazard. Mater. 192: 54-61

Gutierrez, M., Reynolds, M.P., Raun, W.R., Stone, M.L., Klatt, A.R. (2010). Spectral water indices for assessing yield in elite bread wheat genotypes in well irrigated, water stressed, and high temperature conditions. Crop Sci. 50: 197-214.

Haboudane, D., Miller, J. R., Tremblay, N., Zarco-Tejada, P. J., Dextraze, L., (2002). Integrated narrow-band vegetation indices for prediction of crop chlorophyll content for application in precision agriculture. Remote Sens. Environ. 814: 16-426.

Hu, H., Zhang, J., Sun, X., Zhang, X. (2013). Estimation of leaf chlorophyll content of rice using image color analysis. Can. J. Remote Sens. 39: 185-190.

Jia, L., Chen, X., Zhang, F., Buerkert, A., Roemheld, V. (2004). Use of a digital camera to assess nitrogen status of winter wheat in the Northern China Plain. J. Plant Nutr. 27: 441-450.

Jurwakar, A.S. Jurwakar, A., Deshbharatar, P.B., Bal, A.S. (1991). Asian Experiences in Integrated Plant Nutrition, 178-201, RAPA. FAO, Bangkok. 
Kiziloglu, F.M., Turan, M., Sahin, U., Kuslu, Y., Dursun, A., (2008). Effects of untreated and treated wastewater irrigation on some chemical properties of cauliflower (Brassica olerecea L. var. botrytis) and red cabbage (Brassica olerecea L. var. rubra) grown on calcareous soil in Turkey. Agr Water Mange. 95: 716724.

Kipp, S., Mistele, B., Baresel, P., Schmidhalter, U. (2014a). Highthroughput phenotyping early plant vigour of winter wheat. Eur. J. Agron. 52, 271-278.

Lee, J. k., Lee, W.B. (2013). Estimation of rice growth and nitrogen nutrition status using color digital camera image analysis. Eur. J. Agron. 48: 57- 65.

Li, F., Mistele, B., Hu, Y., Chen, X., Schmidhalter, U. (2014). Reflectance estimation of canopy nitrogen content in winter wheat using optimized hyperspectral spectral indices and partial least squares regression. Eur. J. Agron. 52:198-209.

Lobos, G.A., Matus, I., Rodriguez, A., Romero-Bravo, S., Araus, J.L, Pozo, A.D. (2014). Wheat genotypic variability in grain yield and carbon isotope discrimination under Mediterranean conditions assessed by spectral reflectance. J Integr Plant Biol. 56: 470-479.

Lukina, E.V., Stone, M. L., Raun, W.R. (1999). Estimating vegetation coverage in wheat using digital images. J. Plant Nutr. 22, 341-350.

Mahida, U.N. (1981). Influence of sewage irrigation on vegetable crops. In: Water pollution and disposal of waste water on land, Tata Mcgrew Hill Pub., New Delhi.

Mistele, B., Schmidhalter, U. (2008). Spectral measurements of the total aerial $\mathrm{N}$ and biomass dry weight in maize using a quadrilateral-view optic. Field Crops Res. 106: 94-103.

Paruelo, J.M., Lauenroth, W.K., Roset, P.A., (2000). Estimating aboveground plant biomass using a photographic technique. J. Range Manage. 53: 190-193. 
Prasad B, Carver BF, Stone ML, Babar MA, Raun WR, Klatt AR (2007). Potential use of spectral reflectance indices as a selection tool for grain yield in winter wheat under Great Plains conditions. Crop Sci. 47:1426-1440.

Pity, Auaerunyawat., Teerasit Kasetkasem., Audthasit Wongmaneeroj, Akinori Nishirara and Rachaporn Keinprasit. (2012). An Automatic Nitrogen Estimation Method in Sugarcane Leaves using Image Processing Techniques. International Conference on Agricultural, Environment and Biological Sciences.

Rischbeck, P., Elsayed, S., Mistele, B., Barmeier, G., Heil K., Schmidhalter U. (2016). Data fusion of spectral, thermal and canopy height parameters for improved yield prediction of drought stressed spring barley. Eur. J. Agron. 78: 44-59.

Sharabian, R.V., Noguchi, N., Ishi, K. (2014). Significant wavelengths for prediction of winter wheat growth status and grain yield using multivariate analysis. Eng. Agr. Environ. Food. 7: 14-21.

Schmidhalter, U., Glas, J., Heigl, R., Manhart, R., Wiesent, St., Gutser, R., Neudecker, E. (2001). Application and testing of a crop scanning instrument - field experiments with reduced crop width, tall maize plants and monitoring of cereal yield. In: Proceedings of the 3rd European Conference on Precision Agriculture. Eds. Grenier G., Blankmore S., agro Montpellier, France, 953-958.

Townsend, P.A, Foster, J.R., Chastain R.A., Currie W.S. (2003). Application of imaging spectroscopy to mapping canopy nitrogen in the forests of the central Appalachian Mountains using Hyperion and AVIRIS. IEEE T Geosci Remote. 41:13471354.

Yadar, R.K., Goyal, R., Sharma, R.K., Dubey, S.K., Minchas, R.S. (2002). Post irrigation impact of domestic sewage effluent on composition of soils, crops and ground water - a case study. J. Environ. Int. 28, 481-486. 


\section{الملخص العربي}

\section{الرصد الأرضي للإستثعار عن بعد لتحديد التأثير التراكمي لمياة ري مختلفة التئة} الجودة علي انتاجية و نمو البطاطس لتصد

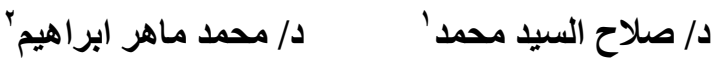

نظر اللزيادة التنافسية علي مياة النيل نتيجة للزيادة السكانية و إستخدامها في مجال الزراعة بنسبة

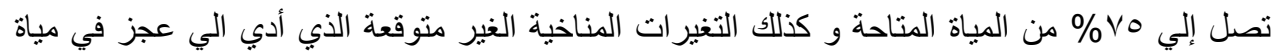

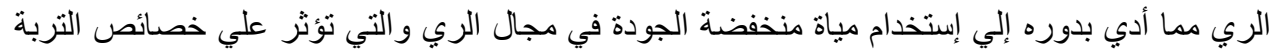

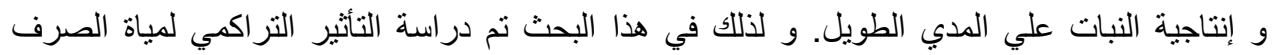

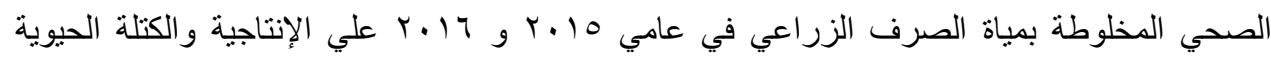

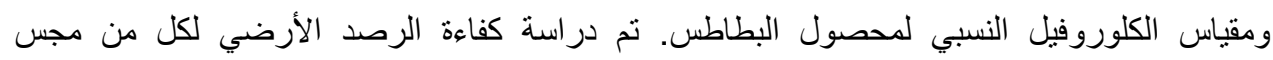

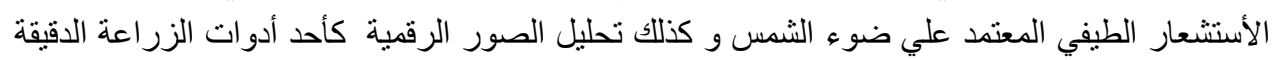

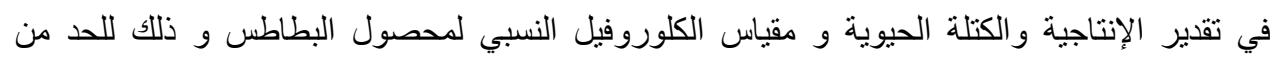
التقدير ات المعطلية التي تتطلب الي تكلفة عالية و عمالة و كذللك العديد من العينات لتغطية مساحات كبيرة. تم تحديد كفاءة كل من مجس الأستشعار الطيفي المعتمد علي ضوء الثمس و كذلك تحليل الصور

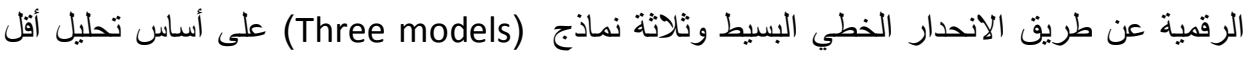
مربع انحدار جزئ (PLSR) التي تساعد بدورها في تحديد التأثثر التراكمي لمياة الصرف الصني الصحي المخلوط علي محصول البطاطس. أوضحت النتائج أن المؤشر الأستشعاري الطيفي /

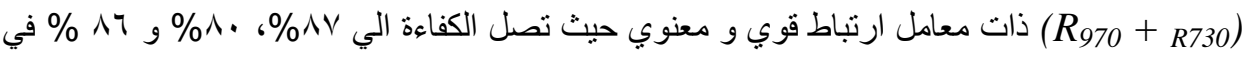
تقدير كل من الإنتاجية، الكتلة الحيوية و مقياس الكلورفيل النسبي لمحصول البطاطس علئ علي التوالي.

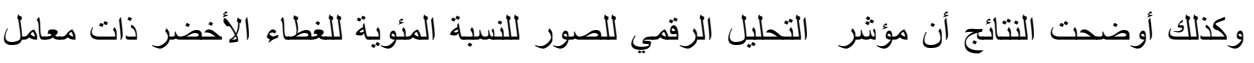

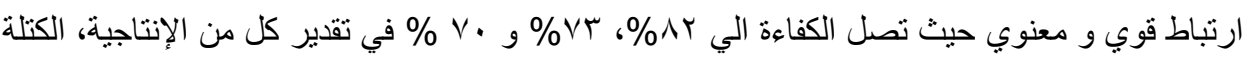
الحيوية و مقياس الكلورفيل النسبي لمحصول البطاطس. بإستخدام النماذج الثناثة (Three models)

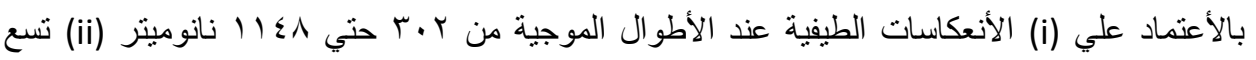

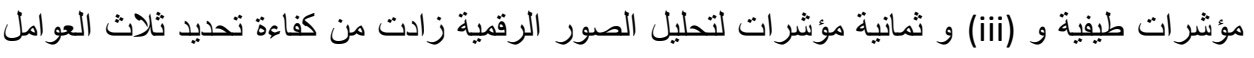

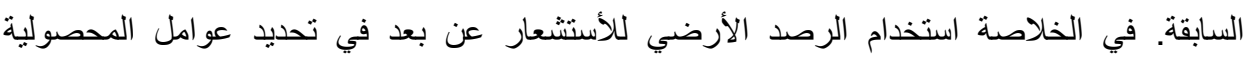
باستخدام التحليل المتعدد (PLSR) أدي إلي تحسين قوة الارنباط بالعوامل المحصولية عن المؤشرات الأستشعارية الفردية لكل من مجس الأستشعار الطيفي المعتمد علي ضوء الشمس و كذللك تحليل الصور

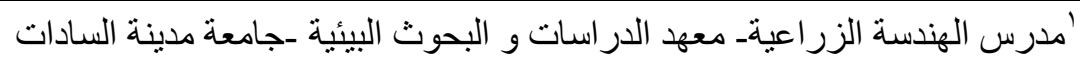

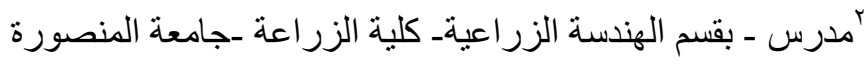

